Faculty Problems and Their Solutions. 4 The report is reputed to be sharply critical of some aspects of the government's affirmative action efforts.

The Lester report would seem to be useful reading for librarians and library educators who should be carefully studying the proposed $\mathrm{HEW}$ regulation. The government is actively seeking suggestions or objections to the proposed rules. Comments should be sent before October 15 to: Peter Holmes, Director, Office for Civil Rights, Department of Health, Education, and Welfare, P.O. Box 2974, Washington, DC 20013.

In addition, copies of comments would be appreciated by ALA's Washington Office.

4 Richard A. Lester, Anti-Bias Regulation of Universities: Faculty Problems and Their Solutions (Berkeley, Calif.: Carnegie Commission on Higher Education; New York: McGraw-Hill, 1974).

\section{Requests for Standards Working Papers}

Due to a clerical error shortly after the New York Conference, copies of the 1959 Standards for College Libraries were sent to persons who had requested, instead, the background/working papers of the committee which is revising the 1959 standards. The ACRL office asks that persons who were affected by this error resubmit their requests. Copies of the papers will be sent upon receipt of the new request.

\section{ALA Goals Award to Standards Project}

The Association of College and Research Libraries has been awarded a J. Morris JonesWorld Book Encyclopedia-ALA Goals Award for 1974/75 by the Executive Board of the American Library Association. The award will fund Phase II of ACRL's project to revise the 1959 Standards for College Libraries.

Phase I of the project to revise the college library standards, which was supported in $1973 / 74$ by a J. Morris Jones-World Book Encyclopedia-ALA Goals Award, was aimed at defining the goals of the standards and the assumptions upon which standards are based. Phase II of the project will enable the members of the committee preparing the revision to discuss the revision with leaders of regional and national organizations in postsecondary education.

The committee is chaired by Johnnie Givens, librarian at Austin Peay State University, in Clarksville, Tennessee. The project director is David Kaser, professor at the Graduate Library School at the University of Indiana. Other members of the committee are: Arthur Monke, librarian at Bowdoin College; David L. Perkins, head bibliographic librarian at California State University, Northridge; James W. Pirie, librarian at Lewis \& Clark College; Herman L. Totten, dean of the School of Librarianship at the University of Oregon; and Jasper G. Schad, director of libraries at Wichita State University, ex officio.

\title{
ACRL Board of Directors Highlights of New York Meeting
}

MET in executive session to discuss the report of the Committee to Evaluate the ACRL Executive Secretary and VOTED that the full report be forwarded to the ALA Executive Director, that the Executive Secretary be commended for her work, and that the process of evaluating the Executive Secretary be continued.

GRANTED chapter status to the Academic and Research Division of the Minnesota Library Association.

HEARD a report from the chairman of the Slavic and East European Section Ad Hoc Committee on the LC Classification System and LC Subject Heading Use in Regard to Slavic and East European Materials.
VOTED to support the recommendation of the ACRL Committee on Interlibrary Communications and Information Networks, to establish an ALA committee on interlibrary cooperation, with divisional representation on the committee.

ACKNOWLEDGED the appointment of the new editor of College $b$ Research Libraries, Richard D. Johnson.

HEARD a report from the editor of Choice.

VOTED to approve as policy the Model Statement of Criteria and Procedures for Appointment, Promotion in Academic Rank, and Tenure for College and University Librarians (including Appendixes) as published in College \& Research Libraries News (Sep- 
tember and October 1973) with the deletion from Section I Paragraph 1 of "... - - or its appropriate equivalent."

RECOMMENDED the establishment of an ad hoc subcommittee of the ACRL Committee on Standards and Accreditation, for the purpose of developing quantitative standards as an addendum to the Guidelines for TwoYear College Learning Resources Programs.

VOTED to refer the matter of the constitutionality of the report of the ALA Standards Committee to the ACRL Committee on the Constitution and Bylaws and instructed the ACRL committee to communicate with the ALA Committee on the Constitution and Bylaws and to formulate an official ACRL position on this issue, to be submitted to the ACRL Board of Directors.

VOTED to recommend affiliation with ALA, through ACRL and its Slavic and East European Section, of the Ukrainian Librarians' Association of America.

INSTRUCTED the ACRL President to write to Unesco concerning the status of the International Bibliography of Social and Cultural Anthropology and to offer ACRL's support for the continuation of the bibliography.

INSTRUCTED the ACRL President to write a letter of thanks to the Clearinghouse and
Laboratory for Census Data and to Vincent R. Barabba, Director of the Bureau of the Census, for their support and participation in the seminar sponsored by the ACRL Education and Behavioral Sciences Section on "Access to Printed and Computerized Census Data."

DISCUSSED the issue of ACRL membership promotion and agreed to give the ACRL President primary responsibility for formulating a plan for promoting membership in ACRL.

DISCUSSED the COO recommendations concerning the ALA Awards Committee and agreed to ask the ACRL President to speak before Council on this issue.

DISCUSSED the COO recommendations concerning the establishment of a joint committee of ALA and the Society of American Archivists and agreed to ask the ACRL President to request that at least one representative to this committee be drawn from the ACRL Rare Books and Manuscripts Section.

\section{ACRL Membership}

June 30, 1974

June 30,1973

12,232

June 30,1972

\section{Announcing a 5th Supplement to the INDEX TO HANDICRAFTS}

The Index to Handicrafts series covers a field of miscellaneous and previously unorganized material on handicrafts and amateur work shop projects. The original Index and four successive supplements cover from roughly 1900 to 1967.

The new Fifth Supplement, by Pearl Turner, covers 1968-1973 and is unique in its inclusion of not only American, but also British titles commonly found in public libraries. Besides indexing over 1,000 book titles, 13 periodicals not indexed by the Readers Guide to Periodical Literature are included, as well as an Index listing all books now still-in-print from the titles in the previous Handicrafts Index and Supplements. The grade level of juvenile books has also been added to this supplement.

For a complete description of the series, write for a copy of Faxon's 1974 Publications Catalog. All previous volumes are available at $\$ 14.00$ each. Order the entire series and receive a $10 \%$ discount. ISBN 0-87305-102-5, Approx. 700pp., Cloth, Approx. \$18.00 net.

\section{Available Summer, 1974}

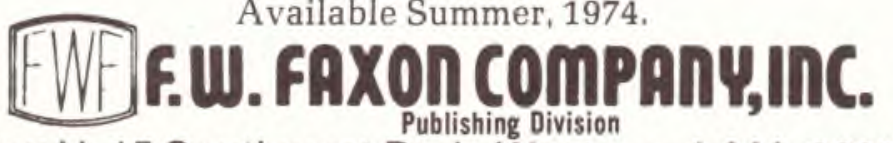

Box H, 15 Southwest Park, Westwood, MA 02090 


\section{THE Series Catalog.}

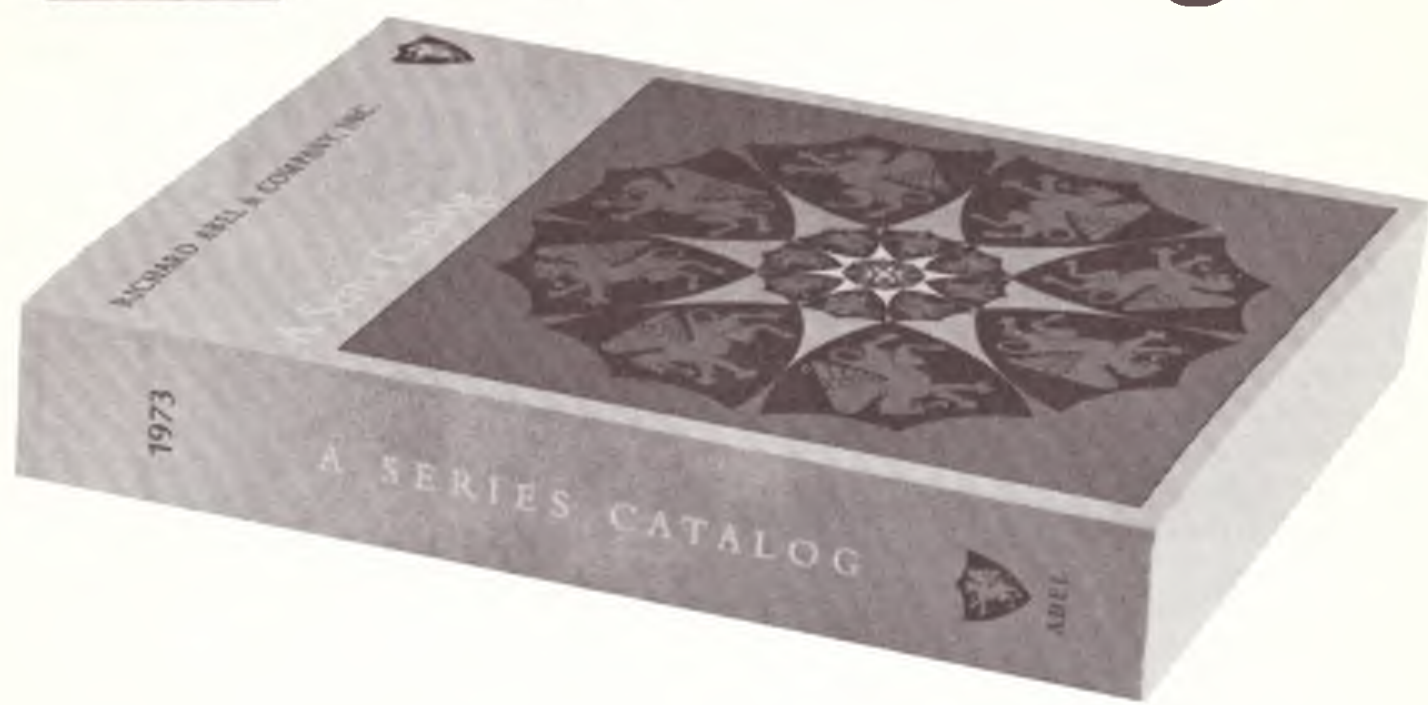

\section{Yours for the asking.}

Richard Abel \& Company's Series Catalog is a unique new reference tool, designed to help librarians verify and order publications in series. It's been called "The most comprehensive listing of series for which any book dealer routinely accepts standing orders." And immediate, fully-automated Standing Order service is available for every series listed in the Catalog (and many more). Your 890-page Series Catalog features:

34,000 Author/Title Entries-28,000 series titles, plus 6,000 essential cross-references.

Classed Subject Index-44,000 entries, under 145 different subject headings.

Price, Frequency and Volume Countprovided to help you budget.

Comprehensive Coverage-of series, sets, editions, non-subscription serials, journal supplements, fascicles, etc.

Bibliographic Integrity-determined and verified by professional librarians and bibliographers.

Your Series Catalog is the key to the surest, most efficient Standing Order service available today. You can verify the existence of a series and its correct entry, and initiate your standing order in almost no time at all. Then you can count on fast Abel service. You can order back volumes with the aid of our history file, and count on receiving future volumes as soon as they're published.

THE Series Catalog sells for $\$ 17,50$. Send us your order today, or find out how you will get your copy free by calling this toll-free number: 800-547-3551

THE SERIES CATALOG

$\square$ Tell me more about your Standing Order services.

$\square$ Tell me how I can get THE Series Catalog free.

$\square$ Send me THE Series Catalog.

My check is enclosed.

Please bill me later.

Name

Library

Address

City/State/Zip

Richard Abel \& Company, Inc.

P.O. Box 4245/Portland, Oregon 97208

(503) 645-3511/Telex 36-0458

OFFICES IN: Mill Valley, Ca. $\bullet$ Los Angeles • Denver • Dallas Kansas City, Mo. - Zion, Ill. - Marion, Oh. - Nashville, Tn Atlanta, Ga. Washington, D.C. Blackwood, N.J. Newton Centre, $\mathrm{Ma}$ - Toronto - London - Amsterdam - Melbourne Sao Paulo. 